U.S. Department of Energy

FreedomCAR and Vehicle Technologies, EE-2G

1000 Independence Avenue, S.W.

Washington, D.C. 20585-0121

FY 2007

\title{
HIGH-TEMPERATURE HIGH-POWER PACKAGING TECHNIQUES FOR HEV TRACTION APPLICATIONS
}

Prepared by:

Oak Ridge National Laboratory

Mitch Olszewski, Program Manager

Submitted to:

Energy Efficency and Renewable Energy FropdomCAR and Wohclo Technologios

Vetwich Syslems Tợm

Susan A Rogers, Technology Developmenl Manager

November 2006 


\title{
HIGH-TEMPERATURE HIGH-POWER PACKAGING TECHNIQUES FOR HEV TRACTION APPLICATIONS
}

\author{
Contract $\mathbf{- 4 0 0 0 0 4 7 0 3 7}$
}

\author{
Submitted by: \\ Fred D. Barlow and Aicha Elshabini \\ Department of Electrical \& Computer Engineering \\ University of Idaho \\ Buchanan Engineering Laboratory, Room 2] ] \\ 607 Urquhart Avenue \\ Moscow, Idaho 83844-1023 \\ Phone: 208-885-7263 \\ Fax: 208-885-7579 \\ E-mail: fbarlow@uidaho.edu \\ Submitted to: \\ Burak Ozpineci \\ Power Electronics and Electric Machinery Research Center \\ Engineering Science \& Technology Division \\ Oak Ridge National Laboratory \\ National Transportation Research Center \\ 2360 Cherahala Boulevard \\ Knoxville, Tennessee 37932-6472 \\ Phone: 865-946-1329 \\ Fax: 865-946-1262 \\ E-mail: ozpinecib@oml.gov
}




\section{DOCUMENT AYAILABALITY}

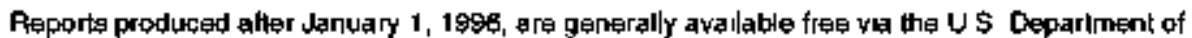
Energy (DOE) Inlomabon Bridge

Wob wite: http //Wun ost gowbindge

Pepports produced befiora January 1, 1996, may be purchased by members of the pubdic from lhe following source

Nalional Technical Informalion Seryce

5285 Fort Royal Road

Springluald, VA 22161

Telephone: $703-605-6000$ (1-800-653-6847)

TOD: 703-487-4639

Fax: $703-605-6900$

E-mali: inlo 9 nus fedworld gow

Web site: http I/wuw nts gowlsupportordemowaboul htrm

Reports are avallable to DOE employees, DOE conlractors, Energy Technology Data Exchange (ETDE) represenialives, and International Nuclear Inlormalion Syskem (IN|S) representatwes from the follewiling aburce

Office ol Scrantilio and Technical Infermalion

PO Box 62

Oak Finge, TN 37891

Tolophon: $865-576-8401$

Fax: 865-576-6728

Emall: reports 由osal gor

Wob site: htp //wunw oel gou/contget html

This report was prepared as an account of work sponsored by an agency ol the Unuled States Government Nerther the Unted States government nor any agency lheiedi, nor arny di their employedes, makes any watranty.

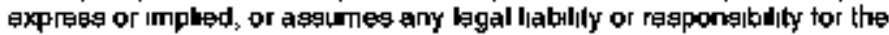
acoursoy. completenese, or uselulness ol any information, apparatus. produol: or procese dischosed, or represents that is use would not infinge

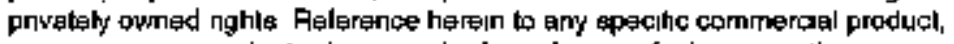
process, or service by Irade name, trademerk, manufacturer, or otherwise, does nol nectessenly conslilule or imply its endorsement, recommendatron, or fawomng by the Unrted States Govemment or any agency thereof The wews and opwons of aulhore expressed heren do not necessarly state of rellect those of the Uhiled States Governiment or any aghency thered 


\section{TABLE OF CONTENTS}

ACRONYMS AND ABBREVIATIONS

iii

EXECUTIVE SUMMARY

jv

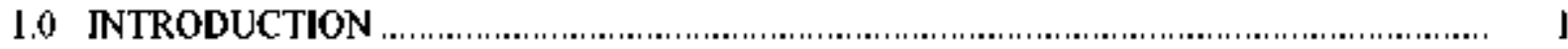

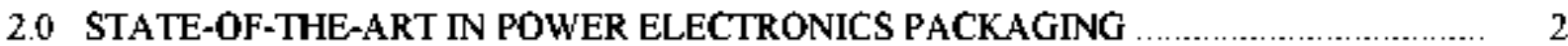

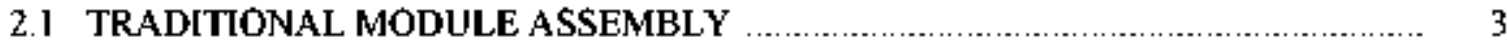

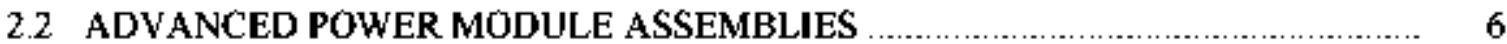

2.3 CURRENT HEV MODULE ASSEMBLIES ......................................................

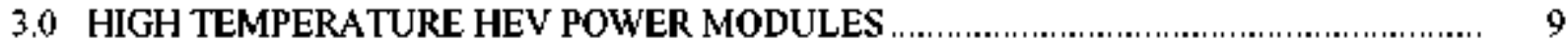

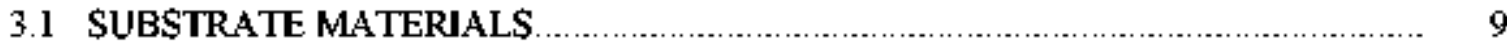

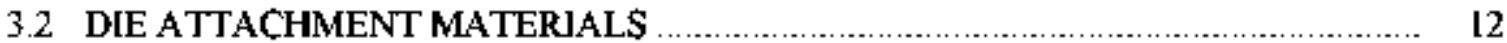

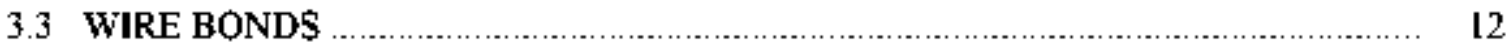

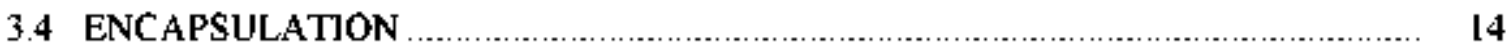

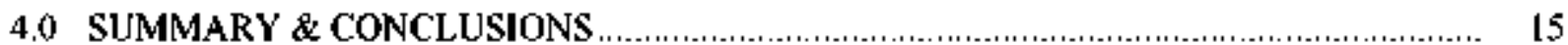

REFERENCES

Figure

\section{LIST OF FIGURES}

$1 \quad$ A pane of $\mathrm{DBC}$ on Alumina and a small etched Ni plated $\mathrm{DBC}$ on AIN board ............ 3

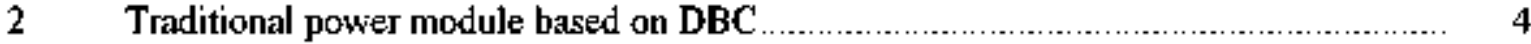

$3 \quad$ Cross section of a traditional power modulc ................................................................ 4

4 Acoustic microscopy image of solder dic bond linc ............................................. 5

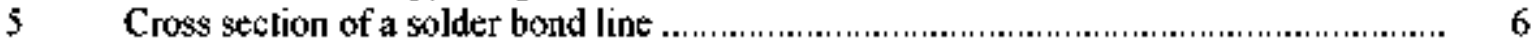

$6 \quad$ Flip-chip bonded power package designed for liquid spray cooling .......................... $\quad$ \&

$7 \quad$ Thermal conductivity of AIN and BeO vs. temperature ....................................... 10

8 Thermal expansion of common ceramics and device materials vs. temperature ............ I ]

$9 \quad$ A prototype flip-chip package .......................................................................... 3 


\section{ACRONYMS AND ABBREVIATIONS}

$\mathrm{ABC}$

AlN

$\mathrm{Al}_{3} \mathrm{O}_{3}$

$\mathrm{AlSiC}$

ANB

amp

$\mathrm{BeO}$

CTE

DBC

DCB

DBA

$\mathrm{GE}$

ICE active braze copper aluminum nitride

Alumina (ceramic substratc)

aluminum silicon carbide

composite base-plates

active metal braze

ampere

Beryillia (ceramic substrate) coefficient of thermal expansion $\left(\mathrm{ppm} /{ }^{\circ} \mathrm{C}\right)$ direct bond copper

direct copper bonding direct bond aluminum General Electric

interual combustion engine
IGBT

IMS

IPEM

HEV

MOSFET

ORNL

PHEV

RoHS

RBC

$\mathrm{Si}$

$\mathrm{Si}_{3} \mathrm{~N}_{4}$

$\mathrm{SiC}$

SIMS insulated-gate bjpolar transistor insulated metal substrate integrated power clcetronics module hybrid-clectric vehicls metal oxide semiconductor field-effect transistor

Oak Ridge National Laboratory plug in hybrid-electric vehicle Restriction of Hazardous Substances Directive regular braze copper silicon silicon nitride (ceramic substrate) silicon carbide secondary ion mass spectrometyy 


\section{EXECUTIVE SUMMARY}

A key issue associated with the wider adoption of hybrid-electric vehicles (HEV) and plug in hybrid-electric vehicles (PHEV) is the implementation of the power electronic systems that are required in these products. One of the primary industry zoals is the reduction in the price of these vehicles relative to the cost of traditional gasoline powered vehicles. Today these systems, such as the Prius, utilize one coolant loop for the engine at approximately $100^{\circ} \mathrm{C}$ coolant temperatures, and a scoond coolant loop for the inverter at $65^{\circ} \mathrm{C}$. One way in which significant cost reduction of these systems could be achieved is through the use of a single coolant loop for both the power electronics as well as the intemal combustion engine (ICE). This change in coolant temperature significantly increases the junction temperatures of the devices and creates a number of challenges for both device fabrication and the assembly of these devices into inverters and converters for HEV and PHEV applications.

Traditional power modules and the state-of-the-art inverters in the current HEV products, are based on chip and wire assembly and direct bond copper (DBC) on ceramic substrates. While a shift to silicon carbide ( $\mathrm{SiC}$ ) devices from silicon ( $\mathrm{Si}$ ) devices would allow the higher operating temperatures required for a single coolant loop, it also creates a number of challenges for the assembly of these devices into power inverters. While this traditional packaging technology can be extended to higher temperatures. the key issues are the substrate material and conductor stability, die bonding material, wire bonds, and bond metallurgy reliability as well as encapsulation materials that are stable at high operating temperatures.

The larger temperature differential during power cycling, which would be created by higher coolant temperatures, places tremendous stess on traditional aluminum wire bonds that are used to interconnect power devices. Selection of the bond melalurgy and wire bond geometry can play a key role in mitigating this stress. An altemative solution would be to eliminate the wire bonds completely through a fundamentally different method of forming a reliable top side interconnect. Similarly, the solders used in most power modules exhibit too low' of a liquidus to be viable solutions for maximum junction temperatures of $200^{\circ} \mathrm{C}$. Commonly used encapsulation materials, such as silicone gels, also suffer from an inability to operate at $200^{\circ} \mathrm{C}$ for extended periods of time.

Possible solutions to these problems cxist in most cascs but require changes to the traditional manufacturing process used in these modules. In addition, a number of emerging technologics such as Si nitride, flip-chip assembly methods. and the elimination of base-plates would allow reliable module development for operation of HEV and PHEV inverters at elevated junction temperatures. 


\subsection{INTRODUCTION}

A key issue associated with the wider adoption of hybrid-electric vehicles (HEV) and plug in hybrid-electric vehicles (PHEV) is the implementation of the power electronic systems that are required in these products [1]. To date, many consumers find the adoption of these technologies problematic based on a financial analysis of the initial cost versus the savings available from reduced fucl consumption. Thereforc, one of the primary industry goals is the reduction in the price of these vehicles relative to the cost of traditional gasoline powered vehicles.

Part of this cost reduction must come through optimization of the power electronics required by these vehicles. In addition. the efficiency of the systems must be optimized in order to provide the greatest range possible. For some drivers, any reduction in the range associated with a potential HEV or PHEV solution in comparison to a gasoline powered vehicle represents a significant barrier to adoption and the efficiency of the power electronics plays an important role in this range. Likewise, high efficiencics arc also important since lost power further complicates the themal management of these systems. Reliability is also an important concem since most drivers have a high level of comfort with gasoline powered vehicles and are somewhat reluctant to switch to a less proven technology. Reliability problems in the power electronics or associated components could not only cause a high warranty cost to the manufacturer, but may also taint these technologies in the consumer s eyes. A larger vehicle offering in HEVs is another important consideration from a power electronics point of view. A larger vehicle will need more horsepower, or a larger rated drive. In some ways this will be more difficult to implement from a cost and size point of view. Both the packaging of these modules and the themal management of these systems at competitive price points create significant challenges.

One way in which significant cost reduction of these systems could be achieved is through the use of a single coolant loop for both the power electronies as well as the intemal combustion engine (ICE) [2]. This change would reduce the complexity of the cooling system which currently relies on two loops to a single loop [3]. However, the current nominal coolant temperature entering these inverters is $65^{\circ} \mathrm{C}$ [3], whereas a normal [CE coolant temperature would be much higher at approximately $100^{\circ} \mathrm{C}$. This change in coolant temperature significantly increases the junction temperatures of the devices and creates a number of challenges for both device fabrication and the assembly of these devices into inverters and converters for HEV and PHEV applications. With this change in mind, significant progress has becn made on the use of $\mathrm{SiC}$ devices for inverters that can withstauld much higher junction temperatures than traditional Si based inverters $[4,5,6]$. However, a key problem which the single coolant loop and high temperature devices is the effective packaging of these devices and related components into a high temperature inverter. The elevated junction tempetatures that exist in these modules are not compatible with reliable inverters based on existing packaging technology.

This report sceks to provide a litcrature survey of high temperature packaging and to highlight the issues related to the implementation of high temperature power electronic modules for HEV and PHEV applications. For purposes of discussion, it vill be assumed in this repont that $200^{\circ} \mathrm{C}$ is the targeted maximum junction temperature. 


\subsection{STATE-OF-THE-ART IN POWER ELECTRONICS PACKAGING}

Power modules have traditionally been tabricated or packaged with one of three core technologies: thick film on ceramic, insulated metal substrates, and direct bond copper on ceramic. Each of these technologies has its niche market due to perfomance and/or cost benefits that lend themselves to particular applications.

Thick films on ceramic substrates such as Alumina are still used in a number of applications due to the relatively low cost of manufacture and their robust nature in the harsh automotive environment. However, this technology is fundamentally limited by conductors that can readily be fabricated and used to interconnect the devices. Since this technology relies on screen printed traces, the interconnects are limited in thickness to a few mils and are lower in conductivity than pure metals due to their cermet nature. Since high current levels are required in HEV and PHEV power modules, this technology' is not idcal for thesc applications sinec the efficiencics and thereforc the vehicle range toould be somewhat diminished in comparison to other packaging technologies.

Insulated metal substrates (IMS) are another technology that is commonly used in power electronic systems. These substrates consist of a copper foil bonded to a metal base-plate with the use of a polymer dielectric. As a result, this technology also suffers from the inability to create very thick conductor traces since the copper must be laminated to the metal support plate. In addition, dhe polymer diclectric greatly limits both the maximum operating temperature of the module as well as the themal menagement since this polymer layer is $10-100$ times lower in themal conductivity than commonly available ceramic substrates. While this layer is in fact thin. its impact on themal perfomance is significant, and as a result IMS technology is prevalent in relatively low power assemblies (less than $1 \mathrm{~kW}$ ) rather than in larger traction drives.

The most common technology found in high power systems is direct bond copper on ceramic. The basic technology was developed in the 1970s and patented by General Electric (GE) in 1976 [7] and enables thick pure layers of copper to be intimately bonded to high thermal conductivity ceramics. The basic process involves placing the copper foil in dircet contact with the ceramic substrate and heating the assembly in a controlled atmosphers. When the oxygen content in the firing fumace is maintained at a low level through the use of nitrogen purge gas and the assembly is heated to $1065^{\circ} \mathrm{C}$, a strong eutectic bond forms between the ceramic and the copper. The reșulting combination provides for very low loss circuit interconnects capable of withstanding hundreds of amperes of current and a strong stable dielectric lay'er. Initially, the technology was adopted for use with Alumina substrates where copper was bonded to both sides in order to create a circuit interconnect structure. This technology is now commonly available for use with Alumina. Beryllium Oxide, and Aluminum Nitride (AIN) substrates and has become the foundation for high power modules based on insulated-gate bipolar transistor (IGBTs), metal oxide semiconductor field-effect transistors (MOSFETs), diodes, and similar components commonly utilized in a die rather than a wafer fomat. As shown in Fig. I, this material can be obtained in a pancl form to be etched or etched to the user's desired specifications by several vendors. The most popular DBC substrate utilizes copper layers ranging from $0.2-0.4 \mathrm{~mm}$ in thickness in conjunction with AIN substrates. AIN is attractive due to the high themal conductivity and low toxicity of this material in comparison to Alumina and Beryllium Oxide respectively. In addition, the thick conductors combined with high breakdown strength of the material make it a natural choice for many applications [8]. 


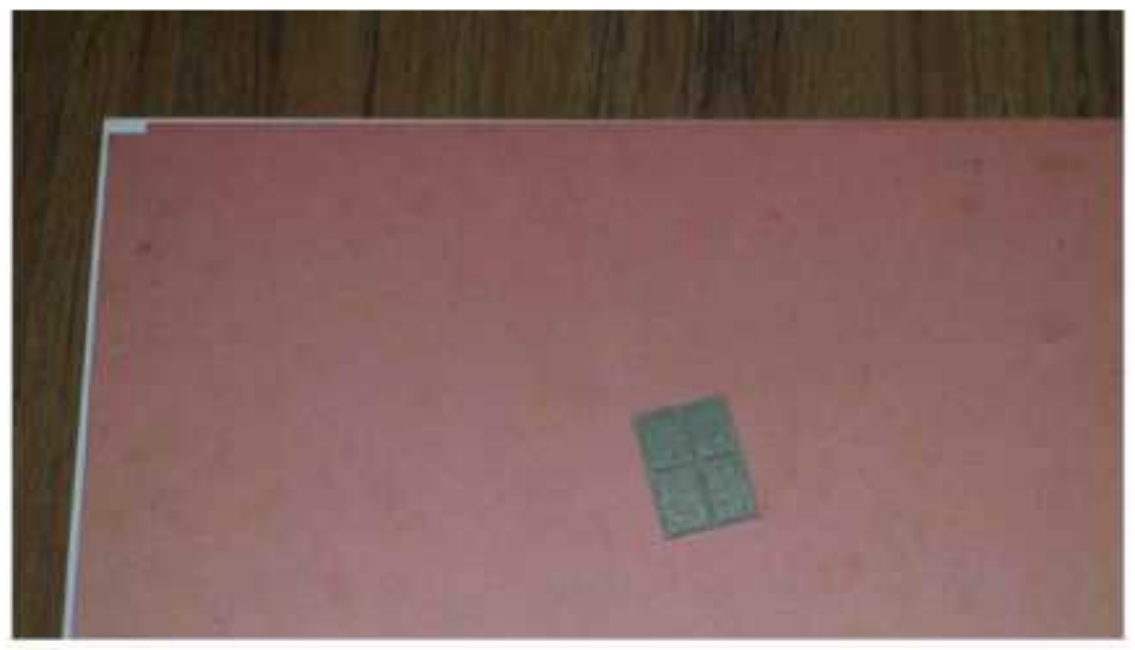

Fig. 1. A pane of DBC on Alumina and a small etched Ni plated DBC on A1N board.

\subsection{TRADITIONAL MODULE ASSEMBLY}

Building on the core DBC technology, a number of assembly methods have been developed over the years to provide reliable power modules at a reasonable cost. The dominate assembly method in use today is illustrated in Figs. 2 and 3. This approach utilizes solder to attach the devices to the DBC substrate(s), as well as to attach the DBC substrate(s) to a metallic base-plate. The copper metal is applied to both sides of the ceramic substrate and generally etched or pattemed on one side only. This patterned side serves as the circuit interconnects, while the backside metal allows for easy mounting of the substrate to the heat spreader. The base-plate acts as a mechanical support for the module and allows for the entire assembly to be securely bolted to a heat sink. In addition to its role in mounting the devices to the DBC substrates, the solder also provides the back-side electrical contact for the power devices. The top side contact to the power devices is provided by aluminum wire bonds which are created between the DBC metallization and the metallization on the device. Historically, the die metallization has been aluminum, and in many cases the substrate metallization has been nickel plated copper. This approach results in a monometallic construction on the die surface that is ideal in terms of avoiding inter-metallic formation. These inter-metallic areas at the bond interface can lead to reduced strength and reliability problems. Ideally, from a wire bond perspective, the substrate metallization would also be aluminum to provide a pure monometallic structure capable of inter-metallic formation. However, aluminum is undesirable as a substrate metallization due the extreme difficulty associated with solder attachment of devices to aluminum. A thin oxide forms on the surface of aluminum when exposed to even small quantities of oxygen and is difficult to remove. This oxide layer inhibits solder wetting and bond formation. Therefore, the industry in large part adopted electroless nickel finishes on DBC substrates to enable high quality wire bonding as well as cost effective die attachment. 


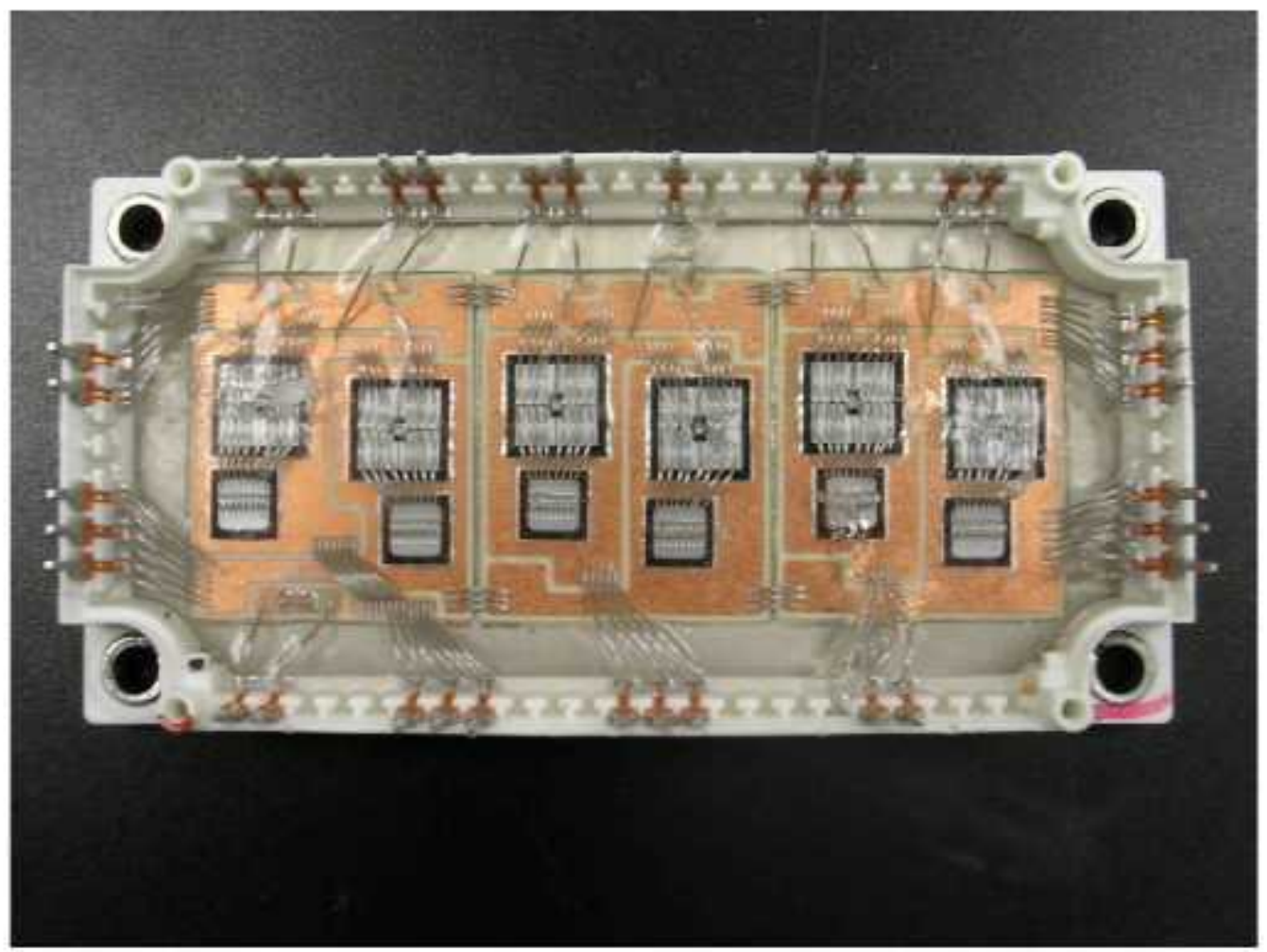

Fig. 2. Traditional power module based on DBC.

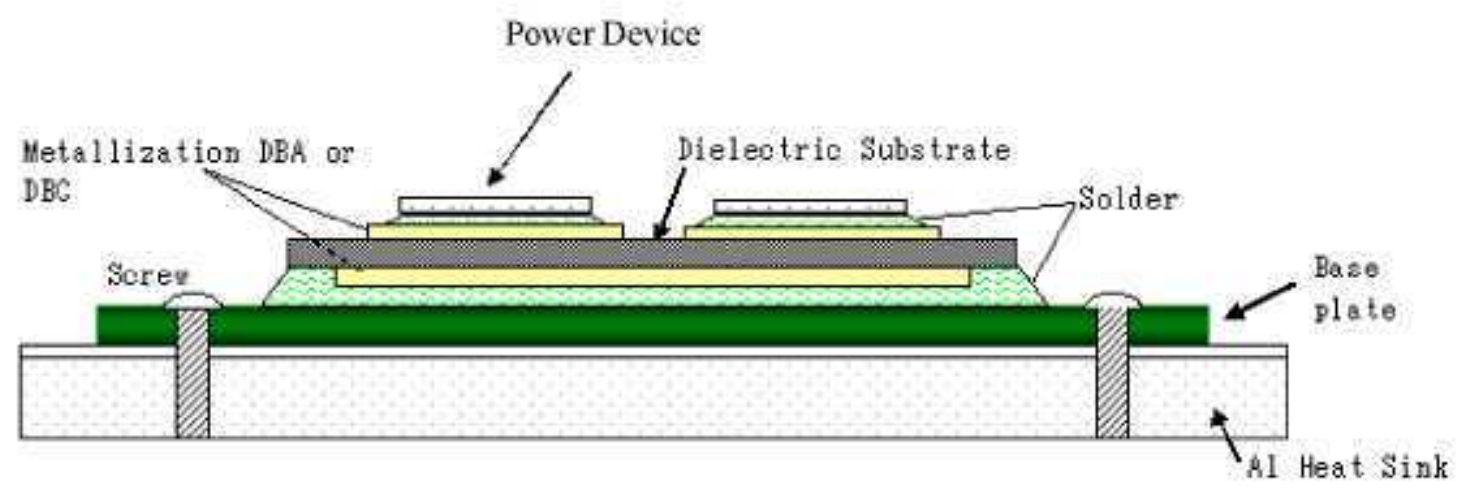

Fig. 3. Cross section of a traditional power module.

This Nickel coating is generally applied with an electroless plating process. This approach is attractive since it coats the edges of the DBC as well as the traces and can be easily applied to etched DBC patterns. One issue with Nickel plated finishes is that bonding difficulty can be experienced on heavily oxidized samples. This problem can easily be avoided by storing samples in an inert atmosphere prior to wire and die bonding and/or removal of the oxide prior to bonding with an appropriate chemical etchant or a plasma cleaning process.

Solders are then used to attach both the power devices to the DBC and the DBC to the base-plate, which is normally made from Nickel-plated copper. Generally, two solder materials are used with dissimilar melting points to allow the die to be first bonded to the $\mathrm{DBC}$, then for the DBC to be bonded to the heat spreader, and the electrical connectors to the DBC without reflowing the die again. It is desirable to have a $25-40^{\circ} \mathrm{C}$ temperature difference between the two solders. While a very large number of possible 
solutions exist for solder materials, the Tin-Lead alloys such as $\mathrm{Sn} 5$ ( $\mathrm{Sn} 5 \% / \mathrm{Pb} 95 \%$ or Sn63 (Sn $63 \% / 37 \% \mathrm{~Pb})$ are attractive due to the low cost, high degree of compliance, strength, and wetting characteristics. Over the last few years, the trend in the industry is away from the lead based solders to alternative materials, such as Tin Silver Copper alloys, in order to meet the Restriction of Hazardous Substances Directive (RoHS) enacted in Europe.

The two primary ways that die are attached is with printed solder paste or with solder preforms. In the first case (printed solder paste), the paste contains a flux and is normally dispensed or screen printed on to the substrates. The die are then placed and then heated in a reflow oven to activate the flux and then melt the solder. The result is a thin bond line of solder (metal) between the die and the substrate or board. This is fast and efficient but can lead to a lack of uniformity in the solder bond thickness and voiding.

The second method uses a thin foil of solder material placed on the substrate instead of the printed solder. These foils are generally referred to as "preforms" in the industry and are cut to roughly the same size as the die. If you examine a prefrom, it appears as a small flat rectangle of metal foil about the thickness of a sheet of paper. A liquid flux in some cases is used with these preforms and the entire assembly is heated as in the printed case to create the solder bond.

This process is well developed and allows for efficient high volume production. Careful process control is required, particularly for the die bonding process in order to minimize void formation in the solder bond. As illustrated in Figs. 4 and 5 , a $\sim 10 \%$ void fraction, or percentage area of voiding, is typical for this process and is acceptable for most products assuming that the maximum single void size is minimized. The use of vacuum soldering can dramatically reduce solder void formation; however, this process is more difficult to execute in a high volume production environment due to the need for a $10-20 \mathrm{~min}$ cycle in a vacuum chamber.

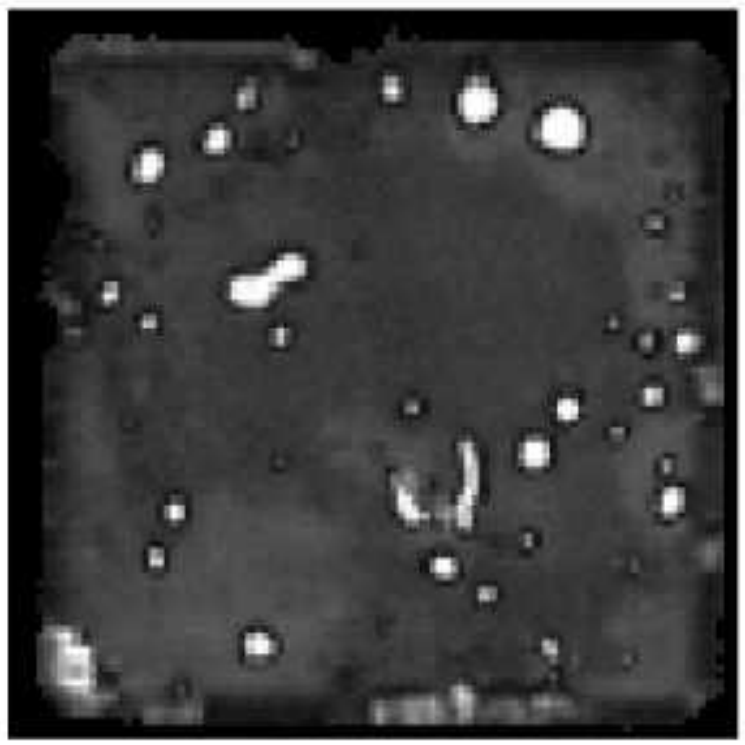

Fig. 4. Acoustic microscopy image of solder die bond line. 


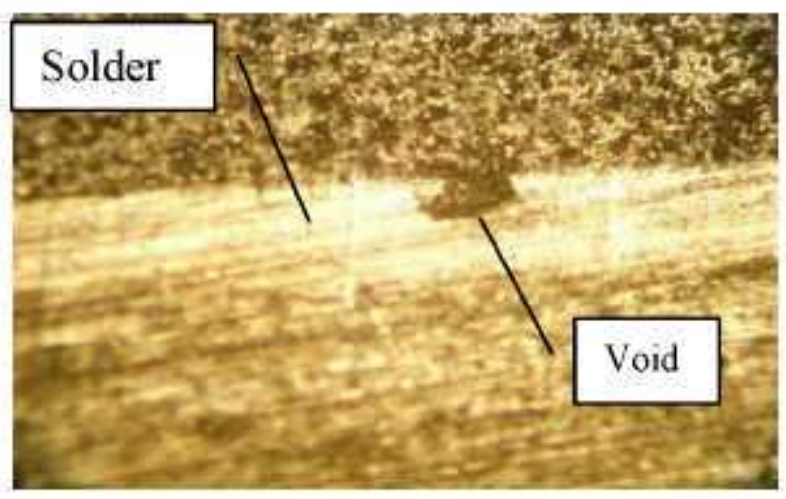

Fig. 5. Cross section of a solder bond line.

Once the entire module has been assembled, these modules have historically utilized a plastic housing molded or bonded to the base-plate in order to provide mechanical protection for the power device and wire bonds, as well as support for the power terminals. Thermosets (such as epoxies) and Thermoplastics (such as thermoplastic polyester) have been used by a number of companies for this application. In older style modules, the electrical leads are soldered directly to the DBC substrates and protrude through the module housing. Many of the newer style modules utilize metal structures integrated into the housings to provide the electrical connections to the external circuitry. Wire bonds are generally used to provide the high current connections between the DBC substrates and these metal terminals. This approach can be more reliable and reduce assembly costs for a range of current densities; however, they are more limited in current density than connectors which are soldered directly to the $\mathrm{DBC}$ conductor $[9]$.

\subsection{ADVANCED POWER MODULE ASSEMBLIES}

It has been recognized within the industry for a significant number of years that the traditional approach to power module fabrication has a number of limitations which include:

- Coefficient of thermal expansion (CTE) mismatch between copper base-plate and DBC substrate.

- Solder void formation in die attachment and DBC to base-plate bond.

- Reliability limitations and parasitic electrical effects caused by wire bonds.

This thermal expansion mismatch between the Si or SiC power devices, with CTE values of $2.8 \mathrm{ppm} /{ }^{\circ} \mathrm{C}$ and $4.2 \mathrm{ppm} /{ }^{\circ} \mathrm{C}$ respectively, and the DBC substrate builds stress into the solder joint and die and can result in failure of the module. A similar effect can also be observed in the bond line between the substrate and the base-plate. Stress in the die bond can be alleviated through the use of compliant die attach materials or by matching the CTE of the substrate and power devices. In most modules, a combination of these techniques is utilized since many solders are available that are somewhat compliant in nature and still offer good electrical and thermal performance. In addition, DBC AIN is a good CTE match to $\mathrm{Si}$ power devices and an excellent match to $\mathrm{SiC}$ power devices. However, the substrate to baseplate mismatch is much more difficult to eliminate in the traditional structure since the substrate options are limited by the need for a high thermal conductivity dielectric. It is technically possible to utilize baseplate materials that are closely matched to the ceramic and therefore greatly improve the overall CTE match, but at an increased cost. A variety of materials such as aluminum SiC composite base-plates (AlSiC), copper graphite metal matrix composites, and copper molybdenum have been developed and are used in the aerospace industry. However, the cost of these materials is significantly higher than the traditional nickel plated copper base-plate, and therefore, these technologies have not enjoyed widespread adoption in the commercial markets. 
Instead of using alternative base-plate materials, a number of manufacturers have developed power module assemblies which do away' with the base-plate and associated solder interface completely in favor of pressure contacts between the DBC substrate and the heat sink. Packages such as the SEMITOP ${ }^{\mathrm{TM}}$ : SKiiPPACK ${ }^{\mathrm{TM}}$, and MiniSKiiP ${ }^{\mathrm{TM}}$ are examples of approaches developed by SEMIKRON Intemational [10-13]. The basic idea is to provide unifom pressure over the DBC substrate in a manncr that provides a solid contact between the back side of the DBC and a heat sink. Since the heat sink and DBC are not bonded together. they are able to expand and contract separately thereby elevating stress that would othenvise build up due to thermal expansion differences in the two materials. Consistent uniform pressure is required to minimize the themal resistance of the interface between the heat sink and the DBC substrate. Withont this pressure, the thermal resistance would be very large and the power ratings of the modules would require considerable derating to maintain reliable device temperatures. Some risks exist in applying pressure to the DBC directly without a base-plate since the ceramic dielectric is far more fragile than a metal base-plate.

Wire bond failure is another key conecm. A recent report illustrated that modules are very reliable if the junction temperatures are limited to $125^{\circ} \mathrm{C}$. However, increasing the junction temperature to $150^{\circ} \mathrm{C}$ creates a temperature difference between the device junction and the coolant loop $(\Delta \mathrm{T})$ of $85^{\circ} \mathrm{C}$. This much larger temperatire difference has been shown to lead to wire bond lift-off in only 41,000 42,800 power cycles. At this point, the delamination in the solder joint between the DBC substrate and base-plate was measured to be only $4.6 \%$ [2]. Therefore, wire bond lifl-off and heel crack formation is a key limiting factor for power modules. The principal problem is the large CTE of the aluminum wite relative to the $\mathrm{Si}$ or $\mathrm{SiC}$ device. As the modulc expands and contracts doc to themal deviations in the wire, deviecs, and substrate, the wires flex and contract in response to these themal excuisions. In contrast, the changes in the devices and substrate are far smaller and the result is stress on the wire bonds. Poorly formed or mechanically damaged bonds may exlibit heel breaks at the location where the wire bends up from the die surface. This mechanical damage may be the result of inappropriate bond parameters, usually too much bonding force and ulirasonic power, or some other physical damage created during assembly or use. These heel cracks may not be visible after the initial assembly, but they grow in response to the stress created duning the modules operation and may lead to premature failure of the module. However, for well formed bonds, the principal failure mechanism is wire bond lift-off where the bond comes loose from the die surface and leaves behind a thin layer of aluminum, followed by' heel cracks creatcd by CTE mismatches in the module [14]. It has been shown that this process of winc bond lift-off begins by crack formation in the bond weld near the die surface [I5]. As the crack propagates, the current density is increased in the surrounding bond area ultimately leading to internuption of the current and lift-off of the wire from the die surface. One possible solution to this problem is the use of molybdenum tabs that are soldered to the die surface. The wire bonds are then formed on the surface of the tabs. which in some cases may be plated with nickel or aluminum. Since the molybdenum has a CTE value $\left(5.1 \mathrm{ppm} /{ }^{\circ} \mathrm{C}\right)$ that is closer to the aluminum wire $\left(23.8 \mathrm{ppm} /{ }^{\circ} \mathrm{C}\right)$ than the semiconductor device $\left(2.6 \mathrm{ppm} /{ }^{\circ} \mathrm{C}\right.$ for $\left.\mathrm{Si}\right)$, this metal tab reduces the stress in the wire bonds and improves reliability [16]. This concept has been known to be effective for a very long time and has been used in a variety of high reliability packaging applications for years [17]. More recently this technique has becn applicd to power modules to improve their overall reliability [18].

Another way in which the industry has worked to eliminate the problems associated with wite bonds is through the use of novel assembly methods which make connections to both sides of the devices with solder or braze alloys. There are a wide variety of these methods, some of which are based on metal clips or structures [19-24], while other methods are based on ceramic [25-27] or polymeric interconnect structures placed on top of the device [28-32]. All of these methods seek to use altemative methods to make the top side electrical connections without wire bonds. An example of one of these packaging methods that was developed (patent pending) is illustrated in Fig. 6. This particular module was designed 
for use with spray cooling and combines a $600 \mathrm{~V}$ IGBT and $600 \mathrm{~V}$ diode into a single flip-chip assembly which is bonded to a DBC substrate and occupies slightly less space than the normal chip and wire approach. The power devices processed to create a solderable metallization on the top surface of the device and are then bumped with solder as shown in Fig, 6 [33-35]. The die is then flip-chip bonded to $\mathrm{DBC}$ and an aluminum nitride heat spreader is used to create the topside electrical contact. This type of approach greatly reduces the inductance of the top side connection and has potential for improved reliability [34].

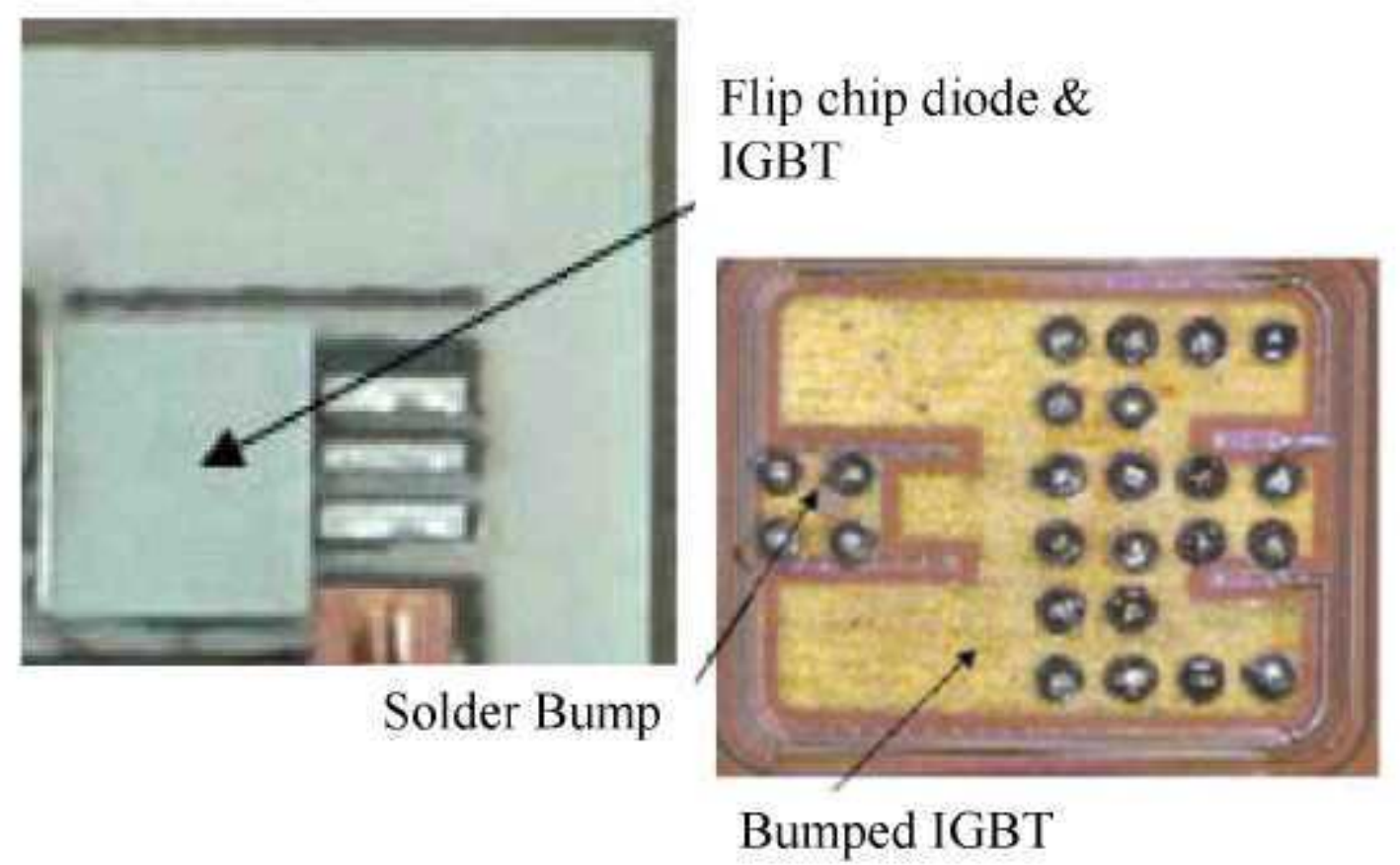

Fig. 6. Flip-chip bonded power package designed for liquid spray cooling.

\subsection{CURRENT HEV MODULE ASSEMBLIES}

Initial electronic components found in HEVs, including the inverters and converters, are based on this traditional module structure. As has been reported and is clearly visible in the images provided in a prior Oak Ridge National Laboratory (ORNL) report ${ }^{\dagger}$ [3], both the Prius converter module and the integrated power electronics module (IPEM) which form the heart of the inverter and boost converter are fabricated with DBC technology, In both cases, IGBTs and power diodes have been bonded to DBC AIN substrates with solder and then wire bonded using heavy aluminum wire bonds. The DBC substrates are soldered to base-plates which are then bolted to coldplates. Water flowing through the cold plates effectively cools the modules. Silicone Gel encapsulation is clearly visible as is commonly used in industry standard modules, such as the one illustrated in Fig. 2. To date, these modules have been able to leverage the traditional technology effectively since the operating temperatures of the module are within the specifications of normal industrial motor drives.

${ }^{\dagger}$ Figures $5,5,5,6,5.7$ on pages 53 and 54, as well as Figs. 5.12 and 5.13 on page 57 from Ref. [3). 


\subsection{HIGH TEMPERATURE HEV POWER MODULES}

In order to develop modules for HEV applications that can operate at high temperatures, a number of key issucs must be addressed in traditional inverter packages. Primanily the issucs are:

- The effect of high temperature on the substrate material.

- Reliability of the conductor material and its adhesion to the substrate.

- Traditional die bonding materials are inadequate for extended use at $200^{\circ} \mathrm{C}$.

- Wire bonds and bond metallurgy must be carefully considered.

- Encapsulation materials must be eliıninated or be stable at high operating temperatures.

\subsection{SUBSTRATE MATERIALS}

In terms of its use for automotive power inverters operating at $200^{\circ} \mathrm{C}$. AlN offers several attractive features, including a close match in CTE to $\mathrm{Si}$ and $\mathrm{SiC}$ as well as good themal stability. For this application while operating at these temperatures, most polymeric substrates are not suitable either due to their low glass transition temperatures or their very low themal conductivities. In contrast, ceramic substrates are viable options at temperatures well above $200^{\circ} \mathrm{C}$, and they offer much higher thermal conductivities than any other viable dielectric option. However, it should be noted that the material properties change significantly with respect to temperature. The thermal conductivity of all the commonly used ceramics decreasc with increasing temperature, as illustrated in Fig. 7 [36-38]. As can be secn from the grapl, AJN substrates offers a themal conductivity of $-170 \mathrm{~W} / \mathrm{mK}$ at room temperatore, which then decreases to $-150 \mathrm{~W} / \mathrm{nl}$ with the exact values somewhat dependent on the vendor. While this effect is undesirable, the change is gradual and can be accounted for in a modules themal design. The CTE of these materials also closely matches $\mathrm{Si}$ and $\mathrm{SiC}$ devices over a wide temperature. as illustrated in Fig. 8 . It is also interesting to note that Dettmer et al. [37] analyzed the effects of high temperature processing on AIN substrates. This analysis involved fiting the substrates repeatedly at $850^{\circ} \mathrm{C}$ and then measuring the thermal conductivity' and surface oxide content using secondary ion mass spectrometry (SIMS). This data illustrates that after five temperature excursions to $85 \mathrm{v}^{\circ} \mathrm{C}$, the thenmal conductivity of the substrates were unchanged and while the top $8 \mathrm{~nm}$ of the substrate was slightly oxidized, no degradation of the substrates was observed. In addition, numerous researchers have denlonstrated the stability of AIN in conjunction with thick film gold metallizations for applications such as instrumentation of jet engines at $500^{\circ} \mathrm{C}$. ambient [39]. One can infer from this testing that the AIN substrates are stable for operating temperatures well above those proposed for HEV applications, as well as any assembly operations that a module might be subjected to.

A separate but related question is the ability of the conductor material in combination with the substrate material to reliably operate at the desired temperatures over the intended product lifetime. For a lower power system. the conductors arc nomally thin so that the substrate cxpansion and contraction is dominaled by the substrate material itself and not the conductor. For a high power system, a thick highly conductive trace is required so that the module losses are minimized. In addition. a trace that is too thin for the required current density may actually fail due to overheating created by the electrical losses in the conductor. Therefore, since this thick conductor is required and all of the good conductors have high CTE values relative to ceramics and power devices, the stresses in a power substrate are mich higher than in a low power substrate. This fact makes the design of power modules more complicated in this respect than low power systems with low current densities. While other options are possible, thick copper layers are ideal due to the high current densities common in the power circuitry. The key issue is the CTE of the copper relative to the ceramic substrate. While no published data on the strength of barc AIN DBC. substrates as a function of thermal cycling is available, this data is available for Alumina [40]. The kcy issue is the thickness of the copper relative to the ceramic, as well as the ceramic strength. In this stody. 
DBC layers thinner than $0.4 \mathrm{~mm}$ (16 mils) are capable of withstanding more than 10,000 temperature shock cycles ${ }^{\dagger}$ from $-40-110^{\circ} \mathrm{C}$ without failure. Very thick copper layers lead to fracture of the ceramic substrate and failure after much fewer thermal cycles. This effect can also be observed in published peel strength data for Alumina and Beryillia DBC substrates, where a decrease in peel strength is observed as the copper thickness increases [41]. Similar analysis conducted by one DBC vendor ${ }^{\ddagger}$ suggests that similar performance is exhibited by AIN DBC. The primary problem with thicker layers tends to be at the lower end of the temperature cycle rather than at the upper end of the cycle. This low temperature failure mechanism can be mitigated by "dimpling" the conductor at the edges of the copper traces. These dimples are simply small holes etched in the top side copper metallization in a regular pattern along the edge of the trace. Dimples effectively reduce the stress at the corners, where the stress is concentrated, and greatly increase the stability of the DBC substrate relative to thermal shock [42]. A recently published report on AIN DBC substrates bonded to $\mathrm{AISiC}$ also confirms this thickness effect; however, it is unclear from this data which solder was used to mount the DBC to the AISiC base-plate, and what role if any this may play in the reliability of the overall structure [43].

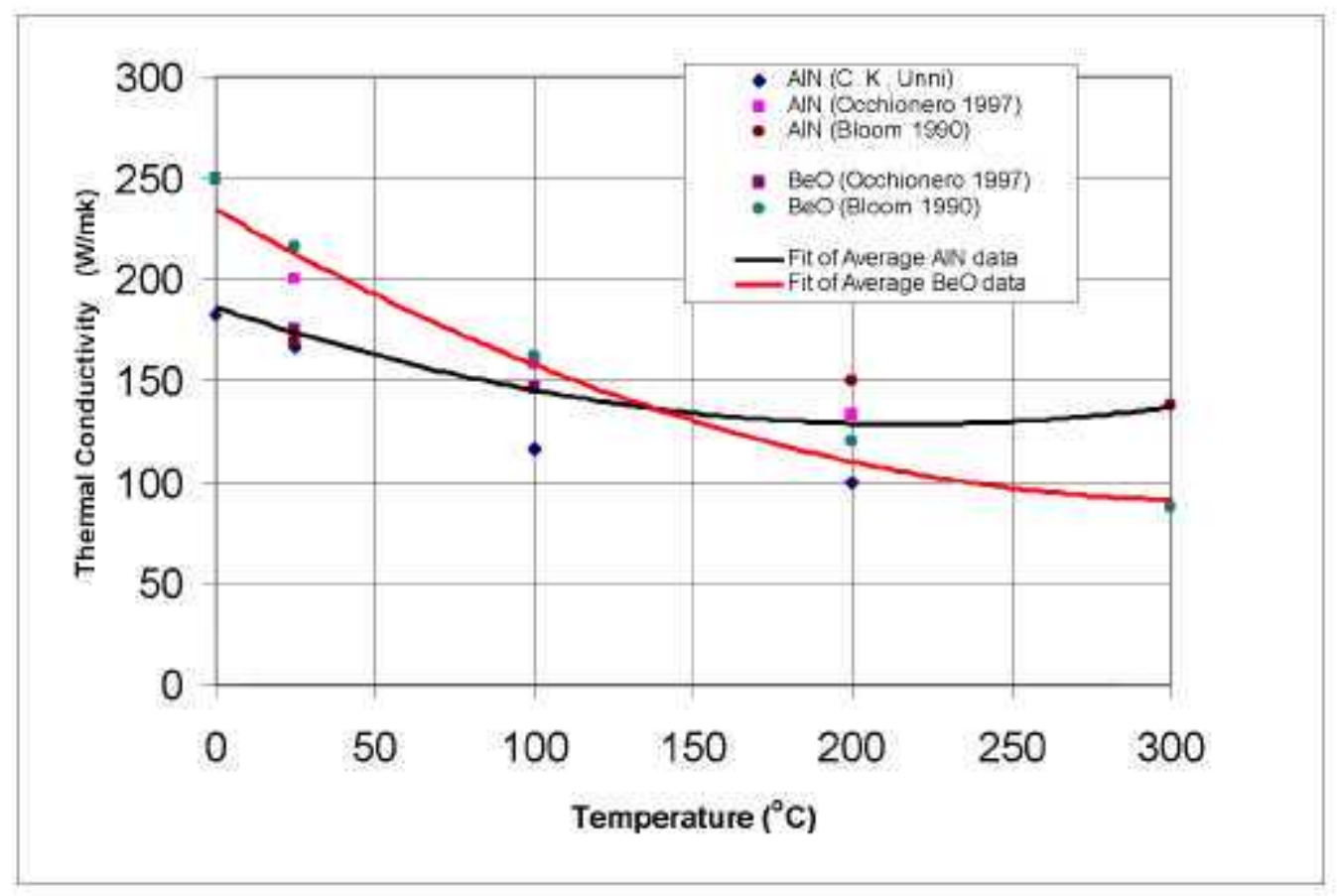

Fig. 7. Thermal conductivity of AIN and BeO vs, temperature.

\footnotetext{
${ }^{\dagger}$ Based on an air-to-air thermal shock with a maximum of three second transfer time between $-40-110^{\circ} \mathrm{C}$ and five minutes maximum time for samples to reach temperature extremes. Total cycle time was 35 minutes [40].

${ }^{ \pm}$Private communication with Curamik Electronics GmbH.
} 


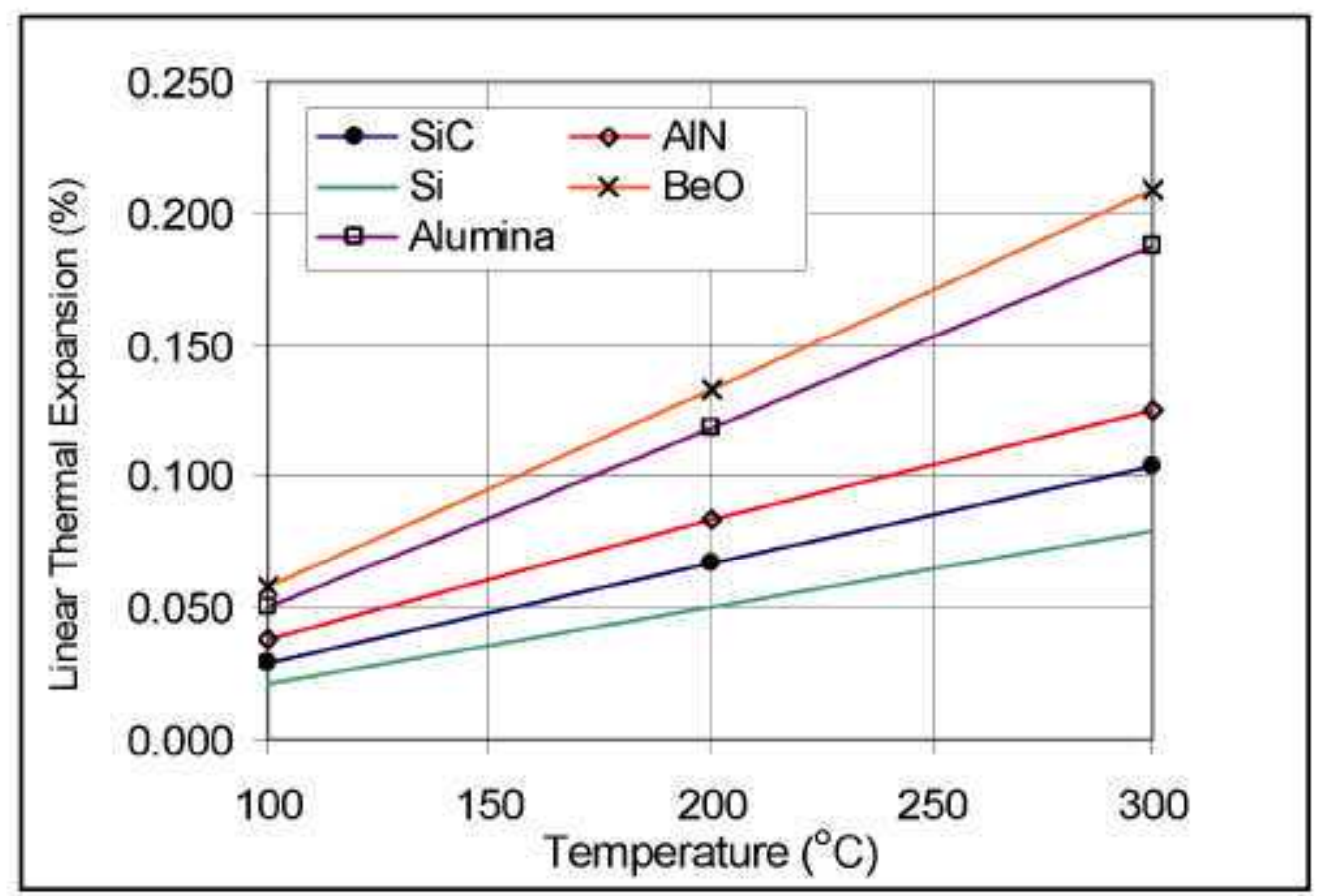

Fig. 8. Thermal expansion of common ceramics and device materials vs, temperature [38].

It is also interesting to note that the overall bond strength of the $\mathrm{DBC}$ substrate may be impacted by the soldering process used to bond the die to the substrate or the substrate to a base-plate. Published data clearly indicates that fluxless soldering processes which utilize hydrogen to inhibit oxide formation can dramatically reduce the bond strength between the copper and ceramic layers [41]. For example, forming gas which contains $10 \%$ hydrogen and $90 \%$ nitrogen and is commonly used in this process, attacks the oxide bond and dramatically weakens the substrate.

An alternative substrate material is direct bond aluminum (DBA) [44]. DBA is very similar to $\mathrm{DBC}$, but the metal layer bonded to the substrate is pure aluminum rather than pure copper. DBA substrates offer slightly lower electrical conductivity and thermal conductivity than DBC substrates; however, published data suggests that DBA substrates may be less prone to delaminating than DBC substrates. This difference is attributed to the aluminum's lower module of elasticity in comparison to copper, which generates lower levels of stress at the DBA to ceramic interface than for copper in the DBC to ceramic interface. While aluminum is significantly higher in CTE than copper, the DBA is constrained to some degree by the ceramic in much the same way as the DBC is constrained by the ceramic substrate [45]. As a result, the CTE of the DBA substrates is only slightly higher than DBC substrates on equivalent thickness ceramic with equivalent metal thickness. This technology is new and more analysis is needed to explore its potential for high temperature modules. However, it should be noted that selectively plating nickel on DBA substrates would allow solder or braze attachment of power devices to nickel and wire bonding of aluminum wires directly to aluminum.

Another altemative substrate material is silicon nitride $\left(\mathrm{Si}_{3} \mathrm{~N}_{4}\right)$ which is now available with DBC metallization (Kyocera). Little published data is available on these materials; however, the $\mathrm{Si}_{3} \mathrm{~N}_{4}$ ceramic is stronger than Alumina or aluminum nitride. Since the failures in most DBC substrates is cracking in the ceramic just beneath the DBC layer, the $\mathrm{Si}_{3} \mathrm{~N}_{4}$ substrates are advertised to be able to better withstand thermal cycling without fracture of the ceramic substrate. 


\subsection{DIE ATTACHMENT MATERIALS}

A very wide range of die attachment methods are in use today. Adhesives are unattractive for these applications duc to their inferior thermal and clectrical conductivity. In addition, it has been shown that while in some cases the bulk themal conductivitics can be improved through the use of filler materials. the interfacial resistance can still be quite high. For power modules. the most common die attach materials are the solder such as the lead tin alloys. These materials offer good electrical and thermal conductivity with a soft compliant nature that absorts some of the stresses created by CTE differences between the die and substrate. In contrast, hard solder's such as high gold content alloys and some braze materials transfer the bulk of the stress to the die and may result in reduced reliability [46]. Many of these soft solders are available with process temperatures well above $200^{\circ} \mathrm{C}$ and are therefore strong candidates for high temperature die attachment in PHEV and HEV applications. The most likely lead based solders are the high lead content allovs such as $95.5 \mathrm{~Pb} 2 \mathrm{Sn} 2.5 \mathrm{Ag}$ or $95 \mathrm{~Pb} 5 \mathrm{Sn}$. With liquidus temperatures in excess of $300^{\circ} \mathrm{C}$. the materials are able to withstand the repeated excursions to high temperatures [47]

Altemative methods are also under development such as lead free solders that conform to the ROHS directive [48], as well as sintered silver die attach methods [49,50]. To date, these methods have not enjoyed wide-spread adoption in the industry. and more analysis is needed to access their suitability for high temperature HEV and PHEV applications.

\subsection{WIRE BONDS}

Two primary issues must be addressed for reliable top side connection to power devices; intermetallic growth and reliability during power/temperature cycling. The top side device interconnect technology that is used in the power industry today is ultrasonic heavy aluminum wire bonding. Aluminum wire is the dominate technology in this industry sinec its soft nature allows the use of much larger wires than is nonnally possible with harder metals [51]. However, aluninum has a low melting point relative to other metals and is susceptible to inter-metallic fonnation if bonded to inappropriate metals. Also, its large CTE as compared to Si devices and common substrate materials can lead to bond lift-off and module failure.

The tendency to form inter-metallic compounds is both a time and temperature dependent phenomenon, and therefore, is exacerbated by operation of the devices at elevated junction temperatures. The most commonly' studied form of aluminum inter-metallic is the series of gold aluminum alloys which form when aluminum wire is bonded to gold metallization [52]. This formation is sometimes referred to as the purple plaguc due to the visible color change ereated by $\mathrm{AuAl}_{2}$ and lcads to bond failure since formation of these alloys creates voids in the bond line and seakens the bond. This process of void formation can occur at temperatures as low as $175^{\circ} \mathrm{C}$ and in time frames as short as 500 hours. While this gold aluminum inter-metallic problem does not occur in power modules since gold is normally avoided, similar potential problems can occnr with other metallization. For example, it bas been documented that aluminum and copper can form inter-metallic compounds that also weaken the bond between the copper and aluminum wire [53]. In this case, the presence of air inhibits the grouth process through the formation of metallic oxides. However, the system still exhibits reduced strength after aging at high temperaturcs. Sone of the test data illustrates an almost $50 \%$ decrease in the pull strengths of these bonds after aging in air for 1000 houss at $200^{\circ} \mathrm{C}$ [53]. Similar decreases bave been measured for aging at $250^{\circ} \mathrm{C}$ and $300^{\circ} \mathrm{C}$. This data shows that initially the bond strength drops within 10 hours of aging, but then levels out with stable bond strengths beyond 400 hours of aging at $300^{\circ} \mathrm{C}$. This would indicate that from an inter-metallic point of view, this technology may have some potential for high temperature operation. provided that the initial drop in bond strength can be accounted for in the module design. 
However, a more reliable although slightly higher cost solution may be the nickel aluminum system. Nickel has been used in microelectronics for a wide variety of applications, but one of its virtues is the very low rates of diffusion of most materials with respect to nickel. It has been documented that aluminum wires bonded to nickel surfaces exhibit very little change in resistivity $(\sim 1 \%)$ when aged at temperature as high as $300^{\circ} \mathrm{C}$ for hundreds of hours [54]. Data also indicates that very minor amounts of diffusion occur between the two materials $[55]$ and minimal amounts of inter-metallic compounds are formed [56]. Destructive pull tests conducted on these samples resulted in wire breaks rather than bond failures indicating that, as desired, the aged $\mathrm{Al}-\mathrm{Ni}$ bonds are stronger than the $\mathrm{Al}$ wire itself. This data suggests that aluminum wire bonds on nickel metallization do not significantly degrade due to intermetallic formation below $350^{\circ} \mathrm{C}$. However, it is also known that plated nickel finishes can become brittle after aging at elevated temperatures; therefore, care must be taken to ensure adequate adhesion between the nickel plating and conductive base copper layer

One way to eliminate the concerns associated with wire bonds and the intrinsic CTE mismatch that exists between the conductive bond wires and the power devices, is to eliminate the wire bonds completely. As discussed in Section 2.2 of this report, manufacturers have begun to implement flip-chip and other wire bondless packaging methods, particularly at the low end of the power range. While all the published methods to date have focused on Si devices rather than $\mathrm{SiC}$ devices, an opportunity exists to exploit these technologies to enable high temperature power inverters for traction drives in PHEV and HEV vehicles. The key positive attributes of this approach include:

- Ability to use more closely CTE matched structures for top side contacts.

- Introduction of lower parasitic inductance and resistance.

- The use of high temperature soft solders would potentially allow these packages to operate at much higher temperatures than traditional chip assembly.

While more work is needed in this area, the authors have developed a prototype package that eliminates wire bonds for high power SiC devices. As illustrated in Fig. 9, this package utilizes a CTE matched lid to connect to the top die surface which is bumped with soft solder spheres. Preliminary data suggests that this type of package has the potential to operate reliably over a wider temperature range than conventional packages.

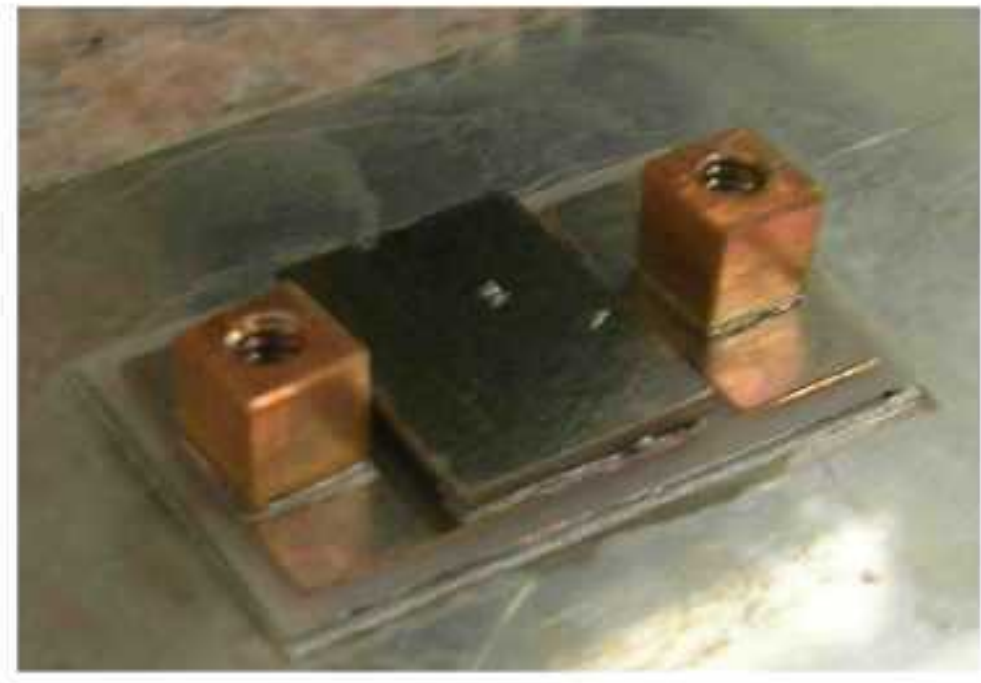

Fig. 9. A prototype flip-chip package. 


\subsection{ENCAPSULATION}

As shown in Fig. 2, conventional modules are encapsulated with a dielectric gel commonly composed of silicone [57-63]. The prineipal purpose of this gel is to improve the breakdown strength of the package by preventing areing between the dic surface, wirc bonds, and adjacent metal features. The material also serves to protect the devices and wire bonds from moisture and contaminants, as well as to aid in reducing mechanical stresses in the devices and bonds. The breakdown voltage of air is approximately $3 \mathrm{kV} / \mathrm{mm}$ but is a strong function of tumidity. In contrast, the dielectric gels have breakdown values of approximately $18 \mathrm{kV} / \mathrm{mm}$, depending on the exact product. GE makes a number of gels [64] as do several other companies. One of the main functions of the get is to suppress arcing in the module. If the gel is not used then the air in the module has a much lower break-down voltage and arcing can occur. Humidity further reduces the break-down voltage of air and can create arcing at much lower voltages than would be possible with the use of a gel. The problem for a $200^{\circ} \mathrm{C}$ junction temperature is that the maximum operating temperature of commercially available gels is $200^{\circ} \mathrm{C}$ or less. This does not leave an adequate safety margin and may result in arcing inside the package and failure of the inverter. New encapsulates that can operate at higher temperatures are needed to enable existing chip and wire technology to be extended to higher temperatures.

For flip-chip package configurations, surface coatings may be adequate to prevent the electrical breakdown of these structures. It has been shown that polyimide coatings which are stable at much higher operating temperatures can effectively prevent arcing along the sides of power devices [65]. The adaptation of this approach to flip-chip power packages wonld enable both high voltage and high temperature operation without the need for improved silicone gels. 


\subsection{SUMMARY \& CONCLUSIONS}

Traditional power modules are based on chip and wire assembly and DBC on ceramic substrates. While this technology can be exiended to higher temperatures, the key issucs arc the substrate niaterial and conductor stability: dic bonding material, wire bonds, and bond metalluryy reliability as well as encapsulation materials that are stable at high operating temperatures. Possible solutions to these problems exist in most cases, but require changes to the traditional manufacturing process used in these modules. In addition, a number of emerging technologies such as $\mathrm{Si}_{3} \mathrm{~N}_{+}$substrates, flip-chip assembly methods, and the elimination of base-plates would allow reliable module development for operation of $\mathrm{HEV}$ and PHEV inverters at elevated junction temperatures. 


\section{REFERENCES}

I. I. M. Miller, "Power Electronics in Hybrid Electric Vehicle Applications." pp. 23-29 in Elghteenth Annat IEE'E Apphed Power Electromes Conference and Exposinon, APEC'03, 1, February 9-13, 2003.

2. G. Coquery, G. Lefranc. T. Licht, R. Lallemand, N. Seliger, and H. Berg, "High Temperature Reliability on Automotive Power Modules Verified by Power Cycling Tests Up to $150^{\circ} \mathrm{C}$," pp. 187]-1876 in Microeleciromcs Reliablin, 439-11), September-November 2003.

3. R. H. Staunton. C. W. Ayers, L. D. Marlino, J. N. Chiasson, and T. A. Burress, Evahlaction of 2004 Toyota Prizs Hubrid Electro Drrve System, ORNL/TM-2006/423, UT-Battelle. LLC, Oak Ridge National Laboratory, Oak Ridge, Tennessee, May 2006.

4. B. Ozpineci, M. S. Chinthavali, L. M. Tolbert, A. Kashyap. and H. A. Mantooth. "A 55 kW ThreePhase [nverter with Si IGBTs and SiC Schottky Diodes." pp. 54 ]-546 in Iwenty-first Ammal Itit Applied Power Electroncs Conference and Expostion. APEC'06, March 19-23, 2006.

5. M. S. Chinthavali, B. Ozpineci, and L. M. Tolbert, "High-Temperature and High-Frequency Perfomance Evaluation of $4 \mathrm{H}-\mathrm{SiC}$ Unipolar Power Deviccs." pp. 322-328 in Twenteth Anmad IEEE Apphed Power Electrontcs Conference and Exposition, APEC 05, 1, March 6-10. 2005.

6. B. Ozpineci. L. M. Tolbert. S. K. lslam, and F. Z. Peng, "Testing, Characterization, and Modeling of SiC Diodes for Transportation Applications," pp. 1673-1678 in IEEE 33rd Anntal Power Electroncs Specialsts Conference, PESC'02, 4, June 23-27, 2002.

7. D. A. Cusano, J. A. Loughram, and Y. S. E. Sun, Direct Bonding of Metals to Cerames and Metals. United States Patent 3,994,430, November 30, 1976.

8. J. Schulz-Harder and K. Exel, "Advanced DBC Substrates for High Power and High Voltage Electronics," ITh European Conference on Power Electrontes and Apptcatons (EPE), Dresden, Germany, 2005.

9. A. Cosacrt, M. Bculque, M. Wolz, O. Schilling, H. Sandmann, R. Spankc. and K. Appelhoff, -Thermal Properties of Power Teminals in High Power IGBT Modules," Proceectings of the Power Converson Inteligent Motion Conference, PCIM 1997, Numberg, Gemany, June 2005.

10. E. Schimanek and G. Mackert, "SKijPPACK with New Driver Principle 'OCP' - The Next Step in Intelligent Power Electronics (OCP - Over Current Protection)," pp. 373-384 in Proceedings of the Power Conversion Inteligent Motion Conference, PCIM 1997. Numberg, Gemany, June 20015.

11. R. Herzer, R. Popp, B. Koenig, and K. Haeup], "MiniSKiiP [I - Benchmark for 600V ClB Modules," pp. 297-300 in Proceedings of The 16th Intematonal Sympositm on Power Semconductor Dences and IC.s, ISPSD'04. May 24-27, 2004.

12. W. Tursky and P. Bcckedahl. "Advanced Drive Systems." pp. 4499-4502 in The $35^{\text {th }}$ Ammual ILEE Power Electroncs Specialsis Conference, Aachen, Genuany, 2004

13. U. Scleuermann, "Reliability of Pressure Contacted Intelligent Integrated Power Modules," pp. 249-252 in Procestings of the Ith Intematronal Symposium on Power Semiconthetor Devices and lCs, June 4-7, 2002.

14. S. Ramminger, N. Seliger, and G. Wachutka, "Reliability Model for Al Wire Bonds Subjected to Heel Crack Failures." pp. 152l-1525 in Mcroetectromes Rehobstrty. 40(8-10). August-October 2000 .

15. G. Lefranc, B. Weiss, C. Klos, J. Dick, G. Khatibi, and H. Berg, "Aluminum Bond-Wire Properties after 1 Billion Mechanical Cycles," pp. 1833-1838 in Microelectroncs Rehabahty, 43(9-11), September-Novenber 2003 .

16. C. Hager, Y. Tronel, and W. Fichtner, "Electro-Thermo-Mechanical Simulations of Aluminum Bond Wires in [GBT-Packages." pp. 163-167 in Techncol Proctedings of the 1998 International Conference on Modehing and Simtiaton of Microsystems, $199 \mathrm{x}$. 
17. D. Palner and F. Galyard, "Aluminum Wire to Thick-Filın Counections for High-Tenperature Operation," pp. 219-222 in IEEE Transcatons on Components. Hybrids, and Manufactnnng Technology, 1(3). September 1978.

I8. A. Hamidi, S. Kaufmann, and E. Herr, "Increased Lifetime of Wire Bonding Connections for IGBT Power Modules." pp. 1040-1044 in IEEE Sixteenth Anntal Apphed Power Etectroncs Conference and Exposmon ( $A P E C^{\prime}$ '2001), 4, March 4-8.2001.

19. F. Barlow, "Chip Scale Packaging for Power Devices," Advancing Mtcroclectroncs Power Electroncs Packaging Issie, 28(4), July/August $200 \mathrm{~L}$.

20. K. Vanam and F. Barlow, High Power Flp Chp Package, Patent Disclosure No. UAF [D04-30, February 2004.

2l. A. Arzumanyan, R. Sodhi, D. Kinzer. H. Schofield, and T. Sammon. "Flip Chip Power MOSFET: A New Wafer Scale Packaging Technique," pp. 25I-254 in Proceedings of the t3th Imtermotonot Symposum on Power Semconductor Devees and ICs. ISPSD 01, June 4-7, 2001.

22. M. Paulasto-Krockel and T. Hanck, "Flip Chip Die Attach Development for Multichip Mechatronics Power Packages," pp. 300-306 in ItLt Transachons on Electroncs Packaging Manufacturing. 24(4), October 2001

23. M. Paulasto. T. Hauck, and A. Kolbock, "Rcliability of Flip Chip Dic Attach in Mulichip Mechatronic Power Modulc,"pp. 93-100 in Proceedings of the th Internotronol Conference on Adhesive Joming and Coating Techtology in Electronscs Monufachurng, June I8-21. 2000.

24. F. Xuejun and S. Haque. "Emerging MOSFET Packaging Techologies and their Thermal Evaluation," pp. 1102-1108 in The Eighth Intersociety Conference on Thermal and Thermomechancal Phenomena in Electrone Systems, JTHERM 2002, May 30-June I. 2002.

25. V. Temple, "'Super' GTO's Push the Limits of Thy'ristor Physics," pp. 604-6 10 in $/ E E E ~ 35^{\text {th }}$ Annual Power Electroncs Specioltsts Conference, PESC'04, 1(1), June 20-25, 2004.

26. C. A. Neugebauer, J. F. Burgess, H. J. Glascock, V. A. K. Temple, and D. L. Watrous, "MCT Packaging:" pp. 908-9l In Proceedings of the t/ Electrontc Compontentw and Technology Conference, 2, May 20-23, 1990.

27. B. Ozmat, V. A. K. Temple, and J. K. Azotea "An Advanced Packaging Technology for High Performance Power Devices," pp. 687-693 in Procedings of the 32nd Infersoctety Energy Conversion Engmeering Conference, 1, July 27-August I, 1997.

28. J. G. Bai, G. Q. Lu, and X. Liu, "Flip-Chip on Flex lntegrated Power Electronics Modules for HighDensity Power Integration," pp. 54-59 in IEEE Tramsactions on Advonced Packagtng. 26(1). February 2003.

29. X. Liu, S. Haque. W. J. Wang, and G. Q. Lu, "Packaging of Integrated Power Electronics Modules Using Flip-Chip Technology" pp. 290-296 in IEEE Foffeenth Armual Apphed Power Electroncs Conference and Exposinon. APEC 2000. 1, February 6-10, 2000.

30. X. Liu. S. Haque, and G. Q. Lu, "Three-Dimensional Flip-Chip on Flex Packaging for Power Electronics Applicatious," pp. 1-9 in IEEE Transactions on Advanced Packaging. 24(1). Februar; $200 \mathrm{~L}$.

31. H. N. Shah, Y. Xiao, T. P. Chow, R. J. Gutmann, E. R. Olson, S. -H. Park, W. -K. Lee, J. J. Connors: T. M. Jahns, and R. D. Lorenz, "Power Electronics Modules for Inverter Applications Using FlipChip on Flex-Circuit Technology," pp. 1526-1533 in Conference Record of the 2004 IEEE Indtstry" Applications Conference and 39th IAS Anntal Meeting. 3, October 3-7, 2004.

32. Y. Xiao, H. N. Shah, R. Natarajan, E. J. Rymaszewski, T. P. Chow, and R. J. Gutmann, "Integrated Flip-Chip Flex-Circuit Packaging for Power Electronics Applications," pp. \$15-522 in IEEE Transactions on Power Electroncs, 19(2), March 2004

33. S. Jittinorasett. F. Barlow, J. McGrath, and A. Elshabini, "UBM Fomution on Single Die/Dice for Flip Chip Applications." pp. 39-44 in Proceedings of the International Conference on Mcroelectronics Packoging, IMAPS, 1999. 
34. J. C. Balda, F. D. Barlow, P. Selvam, and A. Elshabini, Drect Cooling of Propulston Drvesy for High Power Density and Low Volume. Final Project Report, ONR Award No. N00014-01-1-0634. March 2005.

35. R. Joshi, M. Rios, C. Tangpuz and E. V. Cruz "Implementation of Pb-free Bumping in Power Packaging," pp. 81-84 in 28th Internatronal Electroncs Mantffoctimg Technology Symposttm, JEMT 2003, IEEE/CPMT/SEMI, July 16-18, 2003.

36. M. A. Occhionero, R.W. Adams, and K. P. Fennessy. "A New Substrate for Electronic Packaging: Aluminum Silicon Cabide (AISiC) Composites," pp. 398-403 in Proceedings of the Forth Anmual Portable by Design Conference. Electroncs Design, March 24-27, 1997.

37. E. S. Dettmer, B. M. Romenesko, H. K. Charles, Jr.. B. G. Carkhuff, and D. J. Merrill. "Steady-State Thermal Conductivity Measurements of AIN and SiC Substrate Materials." pp. 543-547 in $I E E E$ Transactrons on Components, Hyhnds, and Manufacturng Technology. 12(4). December 1989.

38. T. R. Bloom, "The Reliability of AIN Power Hybrids Using Cu Thick Film Conductive." pp. III115 in Proceedings of the $40^{\text {th }}$ Electronc Components and Technology Conference, 1, May 20-23, 1990 .

39. G. W. Hunter, P. G. Neudeck, R. S. Okojie, G. M. Beheim, J. A. Powell, and L. Chen. "An Overvicw of High-Temperature Elcetronics and Sensor Development at NASA Glenn Rescarch Center," pp. 658-664 in Tronsactrons of the A.SME, 125, October 2003.

40. W. Martin. B. Waibel, and W. Laaser. "Thermal Resistance and Temperature Cycling Endurance of DBC Substrates," pp. 29-33 in Hybrid Cmcutts: Jotmal of the Infernatnonal Soctety for Hybrid Microelectromcs-UK, May 1990.

4I. K. H. Dalal and J. F. Dickson, "Design Trade-Ofts and Reliability of Power Circnit Substrates with Respect to Varying Geometrical Parameters of Direct Copper Bonded $\mathrm{Al}_{2} \mathrm{O}_{3}$ and $\mathrm{BeO}$;" pp. 923-929 in Industry Applicotions Conference and Thrtseth IAS' Annwol Meeting. [AS'95, 1, October 8-12, 1995.

42. J. Schulz-Harder, "Advantages and Ncw Development of Direct Bondcd Copper Substratcs," pp. 359-365 in Microelectromcs Reliabilny, 43(3), March 2003.

43. L. Dupont, Z. Khatir, \$. Lefebvre, and \$. Bontemps, "Effects of Metallization Thickness of Ceramic Substrates on the Reliability of Power Assemblies Under High Temperature Cycling," pp. 17661771 in Mcroetectroncs and Rehabihty, 46(9-11), September-November 2006.

44. A. Lindemann and G. Strauch, "Properties of Direct Aluminum Bonded Substrates for Power Semiconductor Components," pp. 4171-4177 in IEEE $35^{\text {th }}$ Anmal Power Electronss Specialists Conference, Aachen, Germany, 2004.

45. T. Evans, "Pure Copper Metallization Technologies," Chapter 5 in Hybrid Microelectroncs Handbook, edited by J. Sergent and C. A. Harper, MeGraw Hill, 1995.

46. K. Meyyappan, P. MeCluskey, and L. Y. Chen, "Thermomechanical Analysis of Gold-Based \$iC Die-Attach Assembly," pp. 152-158 in IEEE Transactions on Device and Materals Rehabilty. 3(4), December 2003

47. F. P. McCluskey, M. Dash, Z. Wang and D. Huff, "Reliability of High Temperature Solder Altematives," pp. 1910-19]4 in Microelectromes and Relobbility: 46(9-1 1), September-November 2006 .

48. D. Huff. D. Katsiș. K. Stinson-Bagbyy', T. Thacker. G. -Q. Lu, and J. D. van Wyk, "Reliability and Microstnucture of Lead-Free Solder Die Attach Interface in \$i Power Devices," pp. 567-568 in IEEE Proceedings of the 42nd Ammual Intemational Rekabikty Physics Symposum, April 25-29, 2004.

49. Z. Zhang and G. Q. Lu. "Pressure-Assisted Low-Temperature Sintering of Silver Paste as an Altemative Die-Attach Solution to Solder Reflow," pp. 279-283 in IEEE Transactions on Electronics Packaging Manufactioring, 25(4), October 2002.

50. G. Q. Lu, J. N. Calata. Z. Zhang, and J. G. Bai, "A Lead-Free, Lou-Temperature Sintering DieAttach Technique for High-Performance and High-Temperature Packaging," pp. 42-46 in Proceedings of the Wixth IEEE (PPMT Conference on High Density Microsystem Design and Packaging and Component Fanture Anatysis, HDP'04, Jnne 30-July 3, 2004. 
51. H. M. Ho, W. Lam, S. Stoukatcl, P. Ratchev, C. J. Vatl, Ill, and E. Bey'ne, "Direct Gold and Copper Wires Bonding on Copper:" pp. 913-923 in Microelectronics Reliability: 43(6). June 2003.

52. G. Haman, Wre Bonding in Micholectroncs: Matertals, Processes. Reltabilty and Yreld. Second Edition, McGraw-Hill Professional, June 1, 1997.

53. D. Olsen and K. James. "Effects of Ambient Atmosphene on Aluminum - Copper Wirebond Reliability," pp. 357-362 in IEEE Transactsons on Hybrds and Mantfacturng Technology. 7(4), December 1984.

54. D. Palmer, "Hybrid Microcircuitry for $300^{\circ} \mathrm{C}$ Operation," pp. 252-257 in IEEE Transacthons on Paris. Hybrds, and Packaging, 13(3). September 1977

55. J. T. Benoit, S. Chin, R. R. Grzybowski, L. Shun-Tien, R. Jain, P. MeCluskey. and T. Bloom. "Wire Bond Metallurgy for High Temperature Electronics, "pp. 109-1 I3 in High Temperoture Electronics Foterth internatsonal Conference, HITEC'98, June 14-I8. 1998.

56. I. T. Benoit. R. R. Grzy bowski, and D. B. Kerwin, "Evaluation of Aluminum Wire Bonds for High Temperature (2WC) Electronic Packaging." pp. III-I 7-23 in Transactions of the Thrd Internatnonat High Temperature tiectromes Conference, $1,1996$.

57. D. Frey, J. L. Schanen, J. L. Auge, and 0. Lesaint, "Electric Field Investigation in IGBT Power Modulcs." pp. 864-867 in Proceedings of the 2004 IEEE Intemottonal Conference on Sold Drelectres, ICSD 2004, 2, July 5-9, 2004.

58. D. Frey, J. L. Schanen. J. L. Auye, and O. Lesaint, "Electric Field Investigation in High Voltage Power Modules Using Finite Element Simulations and Partial Discharge Measurements," pp. 10001005 in Conference Record of the 38th $1 A 5$ Ammual Meenng in Industry Applicathons, 2, October 12$16,2003$.

59. J. L. Ange, O. Lesaint, D. Frey, and J. L. Schanen, "Optical and Electrical Investigation of Dielectric Gel Behavior Under High Electrical Field,"pp. 912-915 in Proceedings of the 2004 IEEE Internothonol Conference on Soltd Dielectrics, ICSD 2004, 2, July 5-9, 2004.

60. F. Brit, D. Malce, and T. Lcbcy, "Investigations on DC Conductivity and Space Change in Siliconc Gcl," pp. 48-51 in Amual Report Conference on Electrical Mstikanon and Dielectnc Phenomena. October 20-24. 2002

6I. M. T. Do, J. -L. Auge, and O. Lesaint, "Optical Measurement of Partial Discharges in Silicone Gel Under Repetitive Pulse Voltage," pp. 360-363 in Proceedings of 2005 Internahonal Symposium on Flectrical Insulating Matertals, ISEIM 2005, 2, June 5-9, 2005

62. G. Mitic and G. Lefranc, "Localization of Electrical-Insulation- and Partial-Discharge Failures of JGBT Modules," pp. 1453-1458 in Conference Record of the 19g9 IEEE Indastry Applicotions Conference and Thro-Fourth IAS Anmal Meenng, 2. October 3-7, 1999

63. T. Lebey, D. Malec, V. Bley, F. Breit, and E. Dutarde, "Contribution to the Dimensioning of the Different Inșulating Materials Uscd in High Voltagc Power Electronics Module Manufacturing," pp. 55-59 in The Fifh Internatronal Conference on Power Electroncs and Drve Systems, PEDS 2003, 1, November 17-20, 2003

64. General Electric Company, GE Advanced Materials-Silicones, http:/www.gefluids.com/gesilicones/

65. G. Mitic, T. Licht, and G. Lefranc, "IGBT Module Technology with High Partial Discharge Resistance:" pp. 1899-1904 in Conference Record of the 2001 IEEF Indtstry Applocatons Conference and Thrty-Sixth IAS Anntal Meetng. 3, September 30-October 4, 2001. 


\section{DISTRIBUTION}

Internal

1. D. J. Adams
2. M. S. Chinthavali
3. K. P. Gambrell
4. E. C. Fox
5. L. D. Marlino
6. M. Olszewski

7. B. Ozpineci

8. L. M. Tolbert

9. Laboratory Records

\section{External}

10. R. Al-Attar, DCX, raa99dex.com.

11. F. D. Barlow, University of Idaho, Department of Electrical \& Computer Engineering, Buchanan Engineering Laboratory, Rm. 2 I , 607 Urquhart Avenue, Moscow, ldaho 83844-1023

12. T. Q. Duong, U.S. Department of Energy, EE-2G/Forrestal Building, 1000 Independence Avenue, S.W., Washington, D.C. 20585 .

13. A. Elshabini, University of Idaho, Department of Electrical \& Computer Engineering, Buchanan Engincering Laboratory, Rm. 2 I , 607 Urquhart Avenuc, Moscow, ldaho 83844-1023

14. R. R. Fessler, BIZTEK Consulting. Inc., 820 Roslyn Place, Evanston, Illinois 60201-1724.

15. K. Fiegenschuh, Ford Motor Company, Scientific Research Laboratory, 2101 Village Road, MD2247, Dearbom, Michigan 48121 .

16. V. Garg, Ford Motor Compary, 15050 Commerce Drive, North, Dearborn, Michigan 48 120-126].

17. G. Hagey, Sentech, Inc., 501 Randolph St., Williamsburg, Virginia 23185.

18. E. Jih, Ford Motor Company, Scientific Research Laboratory, 2111 Village Road, MD-1 170, Rm. 233 L, Deartom, Michigan 48121.

19. K. J. Kelly, National Renewable Energy Laboratory, 1617 Cole Boulevard, Golden, Colorado 80401 .

20. A. Lec. Daimler Chyssler. CIMS 484-08-06, 800 Chrysler Drive, Auburn Hills. Michigan 483262757.

21. F. Liang, Ford Motor Company, Scientific Research Laboratory, 2101 Village Road, MD 1 70, Rm. 233 I/SRL, Dearbom, Michigan 48121.

22. M. W. Lloyd, Energetics, Inc., 7164 Columbia Gateway Drive, Columbia, Maryland 21046.

23. M. Mehall, Ford Motor Company. Scientific Research Laboratory', 2 lol Village Road, MD-2247. Rm. 3317. Deartom. Michigan 48 124-2053.

24. N. Olds. United States Council for Automotive Research (USCAR), nolds (àuscar.org

25. J. Rogers, Chemical and Environmental Sciences Laboratory. GM R\&D Center. 30500 Mound Road. Waren, Michigan 48090-9055

26. S. A. Rogers, U.S. Department of Energy: EE-2G/Forrestal Building, 1000 Independence Avenue, S.W., Washington, D.C. 20585.

27. G. S. Smith, General Motors Advanced Technology Center. 3050 Lomita Boulevard, Torrance. Califomia 90505 .

28. E. J. Wall, U.S. Department of Energy, EE-2G/Forrestal Building, 1000 Independence Avenue. S.W. Washington, D.C. 20585

29. B. Welchko, General Motors Advanced Technology Center, 3050 Lomita Boulevard, Torrance, Califomia 90505 .

30. P. G. Yoshida. U.S. Department of Energy, EE-2G/Fortestal Building, 1000 Independence Avenue, S.W., Washington, D.C. 20585. 